\title{
PATTANI UNITED LIBERATION ORGANIZATION: FROM JIHAD TO LOCAL POLITICS MOVEMENT
}

\section{ORGANISASI PEMBEBASAN PATTANI BERSATU: DARI JIHAD KE GERAKAN POLITIK LOKAL}

\author{
Bayu Mitra Adhyatma Kusuma \\ Institute of Southeast Asian Islam, Sunan Kalijaga State Islamic University, Yogyakarta \\ Master of Political Science Alumnus, Burapha University, Thailand \\ bayumitraa.kusuma@yahoo.com \\ Theresia Octastefani \\ Department of Politics and Government, Gadjah Mada University, Yogyakarta \\ Master of Political Science Alumna, Burapha University, Thailand \\ theresiaoctastefani@gmail.com
}

\begin{abstract}
In the Kingdom of Thailand, politics and governmental system have close relation with Buddha as official state religion. Moreover Thai government implementing assimilation policy and determine Buddhist Thai as a single national culture and identity. These Thai government autocracy causes the emerged of various resistance group; among other is Pattani United Liberation Organization (PULO) which established in 1968. The research result showed that from the perspective of Thai government, PULO is rebellion, separatist and terrorist. But from the perspective of Malay Muslim in the south, PULO is manifestation of jihad, struggle and heroism. In the beginning, PULO was established in order to fight toward Thai government discrimination toward Malay Muslim in Pattani. But later, PULO's movement orientation is converted as local politics movement which tries to obtain authority to manage Pattani. Moreover hardly they also try to establish Pattani Darussalam state through political of identity issues for getting public attention.
\end{abstract}

Keywords: PULO, Jihad, Local Politics, Political of Identity

\begin{abstract}
ABSTRAK
Di Kerajaan Thailand, sistem politik dan pemerintahan memiliki hubungan erat dengan agama Budha sebagai agama resmi negara. Lebih dari itu pemerintah Thailand juga menerapkan kebijakan asimilasi budaya dan menentukan Budha Thailand sebagai budaya dan identitas tunggal nasional. Otokrasi pemerintah Thailand tersebut menyebabkan munculnya berbagai kelompok perlawanan; antara lain Organisasi Pembebasan Pattani Bersatu (PULO) yang didirikan pada tahun 1968. Hasil penelitian
\end{abstract}


menunjukkan bahwa dari perspektif pemerintah Thailand, PULO adalah pemberontak, separatis dan teroris. Tapi dari perspektif Muslim Melayu di selatan, PULO adalah manifestasi dari Jihad, perjuangan dan kepahlawanan. Pada awalnya, PULO didirikan untuk melawan diskriminasi pemerintah Thailand terhadap Muslim Melayu di Pattani. Namun kemudian, orientasi gerakan PULO berubah menjadi gerakan politik lokal yang mencoba mendapatkan kewenangan untuk mengelola Pattani. Lebih dari itu secara lebih keras mereka juga mencoba mendirikan negara Pattani Darussalam melalui isu politik identitas untuk mendapatkan perhatian publik.

\section{Kata-kata Kunci: PULO, Jihad, Politik Lokal, Politik Identitas}

\section{A. INTRODUCTION}

Many countries have shown that the religion has a very close link with the politics and governmental system. So it can be said that religion has become an integral part of the history of politics and government in many countries (Kusuma, 2015:1). For example are politics and government relations with Buddha in the Kingdom of Thailand. Moreover Buddha is the official state religion of Thailand. Approximately $95 \%$ of the Thailand populations are followers of Theravada Buddhism. But beyond these facts, there are some people who are Muslims with Malay ethnicity. The Muslims are a significant minority group in Thailand. They are the second largest minority next to the Chinese (Aphornsuvan, 2003:3). Generally, they life in the southern part of Thailand, namely the provinces of Pattani, Yala and Narathiwat, coupled with Satun and Songkhla which is directly adjacent to the territory of Malaysian Kingdom precisely Kedah, Kelantan and Perak. The largest Muslim populations are in the Pattani Province which reached around $80 \%$ from whole population. But unfortunately that difference is not producing cultural treasures that coexist but resulted in a collision, both between Muslims and the Thailand government as well as the Muslim and Thai Buddhist society.

Such as minorities population in general, where they often got the discriminatory actions by the Thai government in social and political affairs. The Southern Thailand region which is the base of the Malay Muslim population is the area of religion and racial conflict which became prolonged regional conflicts. Moreover when the Malay Kingdom in Pattani was abolished in 1902, the Pattani Malay population is in a very stressful situation. The Malays have become victims of cultural assimilation policy. Even until nowadays, the minority Pattani Muslim community faced the complex discrimination and protracted terror. So that the social and political life is became very limited. This is similar to what was said by Mahmud (2004:2) above:

"The dispute on the border of the country took place all over the world all the time. Not a few soldiers and civilians were killed before the Golan Heights fall into the hands of Israel, India 
and Pakistan argue to this day to reaffirm the right of Kashmir. Similarly, the issue of Pattani, Mindanao, Aceh, East Timor, Batu Puteh Island, LayangLayang Island and the Spratlys, claimed by Malaysia. Golan Heights lush, beautiful Kashmir to tourists, a Spratly which strategic and laden with petroleum alleged in the belly of its land, the site of the Babri Mosque as a religious sentiment earlier - all this be a reason for conflict, strife and struggle."

National interests in the border of a countries are enormous because the border region enough to affect the security, integrity and sovereignty of a state (Sanak, 2014:15). So that's why, the condition of the Malay Muslim minority populations in Southern Thailand were depressed as this need for understanding from all stakeholders in order to bring Muslim communities coexist peacefully with other communities in Thailand. Because if left, it will be cause a big problem such as security problem and even the emergence of bigger separatism conflict.

The social and political discrimination received by the Muslim Malay community in Southern Thailand, coupled with economic inequality which is evident in per capita income of Thailand population causing unrest and resistance in Southern Thailand. Economic inequality shows that in 1983 Muslims in the South Thai has a per capita income of THB 16,148, while the city of Bangkok has a per capita income three times as much about THB 51,441 (Biel et al, 2005).
This condition triggering the struggle against injustice and oppressive regimes - often also referred as local colonialism - which the Muslim communities in Southern Thailand, Pattani particularly, defined as jihad. Jihad which they did originally just intended to take the fight to the Buddhist Thai government, which has been arbitrarily impose highly controversial policy of assimilation and can remove the hallmark of Malay culture and Islamic tradition which they maintain. Forced assimilation process occurs on a massive scale, especially during the regime of General Phibul Songkhram and in modern times coupled by Thaksin Shinawatra. Besides that, the Thai government determine that Buddhist Thai as the only one national culture and identity. This resistance movement led to various resistance organizations, one of the biggest and most famous is the Pattani United Liberation Organization or PULO. PULO was established in 1968 by Kabir Abdul Rahman, a Pattani Malay scholar. PULO's platform is Islamic nationalist goals; calling the Thai presence in Pattani is colonization and illegal occupation.

Muslim has much experience both as minorities or majorities within a region. They were initially minorities in Mecca and later when Muslim hijrah to Abyssinia and Medina (Siddiqi, 2006). It became the inspiration for Muslims in Southern Thailand or in another corner of the world where Muslims are a minority. These conditions are clearly different compared when Islam became a majority such as Indonesia and Malaysia. Furthermore in Malaysia was 
formally declared Islam as the official state religion (Suaedy, 2010:3). Regardless of ethno-religious conflicts that occur, Muslims in Southern Thailand in the contemporary period has experienced a significant improvement in various fields. Although they are remain under pressure and discrimination from the Thai government. Muslim community in Thailand is not a new phenomenon and is not marginalized communities. Therefore Muslims in Thailand today is an integral part of society as a whole Thailand and remain a minority in various fields, especially social or political. The Muslims today just as the past continue to be numerically and politically significant as national minority in modern-day Thailand (Jory, 2007:212). So that their jihad movement has been converted to local politics movement, where they want to have an authority to regulate the Pattani region by their self and even more extremely they want to secede from the Kingdom of Thailand to establish a state namely Pattani Darussalam.

Based on the above facts, it becomes interesting to study further about PULO, in particular how the concept of jihad that is manifested as a resistance movement against oppression and injustice converted into local politics movement which aims to get the authority to manage Pattani through local autonomy or separate from the Kingdom of Thailand. So that's why the authors determined to take a research title namely "Pattani United Liberation Organization: From Jihad to Local Politics Movement". This study aims to determine, describe and analyze about the PULO's existence and their movement from jihad to local politics movement.

\section{B. THEORETICAL FRAMEWORK 1. Pattani United Liberation Organization (PULO)}

Western impact that drove Siam to secure its independence and modernization also gave the MalayMuslim states an opportunity to assert its own autonomous state and religion vis-à-vis the modernized Thai nationstate (Aphornsuvan, 2003:14). In 1950 and beyond, the relationship of Malay Muslim in Southern Thailand with Thai authorities covered by mistrust, suspicion and misunderstanding are protracted. They are isolated from the State and the government, not only because the central government is far from that area, and alienation from the state, but more due to the differences in religion, language and culture (Kusuma, 2015:13). It became a trigger of the Pattani United Liberation Organization (PULO). Originally PULO was a movement organization which established by Tengku Bira Kotantila also known as Kabir Abdul Rahman in 1968. This organization was founded on the basis of his observations of what is happening in southern Thailand. He felt the need for an umbrella organization to change the condition and fate of the ethnic Malay Muslims who live in southern Thailand that he considered full of discrimination, inequality, and the pressure from the Thai government after the collapse of the Sultanate of Pattani. 
To free themselves from the shackles of Thai government policy, Kabir Abdul Ranchman further pursues all ways to liberate the Malay Muslims who are oppressed. To achieve this goal, certainly need a strong mass base. To recruit the mass base, the organization uses the ideological foundation "Religion, Race, Homeland, and Humanitarianism". With the ideological foundation, PULO can embrace all classes and walks of Malay Muslims in southern Thailand. To achieve this, there are two methods used by the PULO, namely: first, by the violent way. Violent way is by arming PULO's members to carry out an attack on the Government of Thailand; Second, by the non-violent way. Nonviolent means of among others such as indoctrinated to expel the Thai from the south. Other non-violent means used is to involve ourselves in providing learning materials in schools to raise awareness of their identity as ethnic Malay Muslims.

\section{The Origin of Jihad}

Jihad comes from the Arabian verb Jahada which means struggling very hard with all of soul to get success in the Allah way. In the Holy Qur'an there is a term of jihad which means to devote absolute capability; these ayat is referred to QS. Al-Ankabut [Spider] (29):8. In the Holy Qur'an, the term of jihad is quite wide, from the inwardly and outwardly efforts, for family, community, state and international affairs that led to the peace and safety. Jihad was actually to be done through dakwah, but it could also be done to fight against enemy attack (Afadlal et al., 2005:138). Therefore, attacking another group without apparent reason is not having the value of jihad. Qur'an does not mention jihad as aggression, violation or brutality as a strategy of Muslims. So the assessment of the western orientalists who identify Islam or jihad with terrorism is a very wrong view.

But for a group of people who have a superficial knowledge or a narrow understanding about the teachings of Islam have turned the noble notion of jihad into negative prejudices and then act radically as terrorism. Jihad is very different from terrorism. Terrorism is the use of violence to generate fear in order to achieve objectives, especially political purposes. It is contradicts from the Islamic value which rahmatan lil alamin or mercy for all part of the world (Jainuri et al., 2003:315). Meaning of jihad that has deviated often result in conflicts. In the beginning of established, PULO run jihad as stated in the Qur'an, which is only to defend themselves. But over time, they also experienced shift actions such as violence and bombings. It was triggered by the Thailand government's repressive measures that seek to eliminate the Malay tradition and identity they have.

\section{Political of Identity as Local Politics Movement}

In the political science literature, identity of politics can be divided into two perspectives, namely political identity and political of identity (Haboddin, 2012). Political identity is a 
construction which determines the position of the subject in the interests of a political community. While political of identity refers to the mechanisms of political organization as a source of identity and political means. Based on these definitions, it is in the context of contemporary political practice, meaning that political of identity as a political source and means in the scramble for political power fights become very possible. This concept is also in line with the opinion of Agnes Heller, who defines political of identity politics as a political aspect that focuses on the distinction as a major category which promises freedom, tolerance and free play, although it gave rise to patterns of intolerance, violence, ethnic conflict. So if it simplified, the coverage of the political of identity among others are related to racism, bio-feminism, and environmentalism (Heller in Abdillah, 2002:22). Kemala Chandra Kirana as cited by Haboddin explained that political of identity is usually used by leaders as political rhetoric. They use "us" for "indigenous people" who want power and "them" for "comer" who have to relinquish power. So it can be said that the political of identity is used as a tool of political manipulation in order to satisfy their respective interests.

Emphasizing on identity actually has its own level of sensitivity and often causing a conflicting endless. This is in line with the thought of Ibn Khaldun who stated that in the connection with the conflict, one of the potential in human beings is a love of group identity. This love produces a feeling of kinship and group self-esteem, loyalty, cooperation and mutual assistance in the face of disasters or threats that will ultimately form a unity group (Sunarto, 1985). Love of the identity then influence to political life. Related to this phenomenon Ibn Khaldun argued that political phenomena associated with the struggle for power and sovereignty were spawned empires, dynasties and state (Affandi, 2004:80). Therefore, in their local political movement, PULO often utilizing the issue of minority-majority and turn it into a problem of identity to attract public attention.

\section{RESEARCH METHOD}

This research is use qualitative method and descriptive analysis approach. Qualitative method is chosen type for this research as a set of nonstatistical inquiry techniques and processes used to gather data about social phenomena. Qualitative research concentrates on the study of social life in natural setting. Its richness and complexity mean that there are different ways of analyzing social life, and therefore multiple perspective and practices in the analysis of qualitative data (Punch, 2004:194). Data collecting method are the strategic step in the research. Data collection techniques used in this research is observation, interview and analysis of related text or document. Observation is done towards Malay Muslim daily life in Thailand among November 2012 until April 2014. Interviews are run toward several Malay Muslim in Thailand, especially are South Thai and several Indonesian people who life in Thailand. While the related text and documents are collected 
from the printed and electronic media. In this study, researcher use qualitative data analysis model of Miles and Huberman (1998) which called interactive model. Data analysis techniques of Miles and Huberman consist from four activities, namely: data collection, data reduction, data display, and conclusion.

\section{RESULT AND ANALYSIS}

Islam does not necessarily exist in the land of Siam. Although Islam is the majority religion in Indonesia, Malaysia, and Brunei Darussalam, but Islam is a minority religion in the mainland of Southeast Asia. In mainland Southeast Asia, however, Islam has been a minority religion and Buddhism is a national religion. Historically the region had been dominated by Hinduism and Buddhism for centuries before the arrival of Islam around the ninth century (Aphornsuvan, 2003:7). Like mentioned above that is from the late 1950 s to the present, relations between the Malay-Muslims of the South and Thai authorities have been relatively the same. Mistrust, patronizing and misunderstanding on the part of the government officials are still prevalent. Fear, resentment and disapproving of Thai rule and power are also rampant among the Malay Muslims. Similar policies aimed at integration and assimilation of the Muslims is still being prescribed to the local offices. In 1970, cleanup operations imposed anti-government movement in the Muslim region of southern Thailand. The pressing circumstances give rise to a strong reaction from the Muslim community with the emergence of the resistance movement and the liberation of Muslim southern Thailand, one of which became the center of discussion in this study, namely Pattani United Liberation Organization (PULO). Which is the motor Pattani Muslim liberation movement and other Muslim regions. According the member of PULO, their movement are "jihad", because they are fight against "toghut" Thai government

From the perspective of Thai government, PULO is viewed as rebellion because they are against toward policy which implemented by the government of Thailand in south Thai. PULO also viewed as a separatist because they want to secede from the Kingdom of Thailand to establish an independent Pattani Sultanate. Besides that, PULO also viewed as terrorist because PULO considered as a security disturbance movement like killing and bombing. But from the perspective of Malay Muslim in the south, PULO is manifestation of jihad, struggle and heroism. It is because PULO is a symbol of Malay Muslim's struggle in achieving their right. The PULO's jihad movements are basically motivated by various factors, namely: First, factor of cultural integration and assimilation policy. The Thai government imposed a policy of cultural integration and assimilation is considered highly discriminatory by the Malay Muslim community because the policy is based on three main principles, namely the "principle of one religion, one empire, and bow to the power of the King" or Thai Rak Thai. Malay Muslims ethnic 
are forced to become one with the Thai ethnic overall. This includes the religious affiliation, language, writing, and procedures of daily living, including dressing. This policy is applied to defend the sovereignty and territorial integrity of Thailand by eliminating the Malay Muslim community identity.

Second, factor of history. Formerly the Pattani Islamic Sultanate was sovereign and independent. After that, since the signing of the AngloSiamese agreement treatment in 1909 in Bangkok, the fifth region in southern Thailand which was once the territory of the Sultanate of Pattani namely Pattani, Narathiwat, Yala, Satun and parts of Songkhla province officially became part of the Kingdom of Thailand. These conditions make the shock identity for Malays ethnic who previously are the majority ethnic and now become minorities ethnic. Being a minority ethnic in a (their own) country of course change the order of their social life drastically.

Third, factor of economy. Postdefeat Sultanate of Pattani, economic life underwent a drastic change. Almost the majority ethnic Malay Muslims live below the poverty line and living in a seedy neighborhood. This poverty is happens because of development inequality by Thai Government. The management of natural resources that are abundant in southern Thailand such as oil, ikam, forest products, and the economic resources others actually be enjoyed by the community of Buddhist and Chinese descent, while the ethnic Malay Muslims who are the natives only works as a complement to the economic order in southern Thailand. They are only employed as unskilled laborers, fishermen, and small sword. This situation makes the ethnic Malay Muslims be eliminated gradually.

Fourth, factor of education. Education which received by the Malay Muslims ethnic in the southern Thailand region is all use Thai language and writing. The Thai government made the Thai language as the single national language. This rule applies to all Thais and for ethnic Malay Muslims. Malay Muslims ethnic considered violated if they continue sending their children to get an education at the cottage and use the Malay language. In addition, the Thai government also changed the lodgment education as compulsory education into additional education. Of course, this education policy is very difficult for the ethnic Malay Muslims to study the educational materials. Not surprisingly, the results of education in the form of graduation were not to be realized. And fifth, factor of culture. Culture shock is another problem that must be faced by Malay Muslim ethnic. They are experiencing cultural shock of having to adapt to the situation and the new rules. Malay Muslim ethnic is life course different from the life of Thai ethnic. These differences include the way of communicate, the way of life, religion, up to a difference in the community how to socialize.

Until nowadays, PULO and Malay Muslims ethnic are still struggling to separate from Thailand, both in the term of area and government. They done many activities 
in local political movement, although in the fact this movement is not find a way yet. They hope that they can receive a conflict resolution from Thai government for giving independence, or at least special autonomy. The desire for separate and build a new state as The Sultanate of Pattani Darussalam is more strength for legitimize their own identity. If we saw the historical records noted that the Sultanate of Pattani known as one of the largest Islamic kingdom in Southeast Asia and also as an Islamic trade center which has big influence in South China Sea waters. From that story, PULO and Malay Muslim ethnic want to repeat their gold history for making a better condition because they felt so uncomfortable for living surrounding Thai peoples. This condition can be happened because Thai peoples give special nickname to Malay Muslims. They called them "Khaek", which means new comers or outsider. This name has political of identity element for distinguish between them. "Khaek" describes a negative meaning, such as: lazy, slovenly, dirty, poor, and etc. Thai peoples consider that Malay Muslims have a lower level than Thai ethnics.

While, Malay Muslims ethnic is do not accepted to be treated as it also has its own designation for Thai ethnics. Malay Muslims called the Thai ethnics as infidels and pagan. They argued that Thai peoples like to suppress them and it seems to jahiliyah groups who must be fought because it is contradictive with Islamist law. So far, Malay Muslim ethnics described that the relationship between Malay Muslim ethnics and
Thai government is like colonies and colonizer, rather than society and government. Thai's government imposes Malay Muslim to change their name into Thai or Buddhist name. If they change their name, it seems like they change all their identity. Thai's government forbid them to use the original name if they won't follow this rule, they can't get job or career promotion. They must leave their original identity for the sake of national interest. Malay Muslim felt so isolate in social, political, and governmental life of Thailand. It also explained by Cliffort Geertz that the dissatisfaction of politics, economics, or social levels can create revolution. But, the dissatisfaction of religion, language, race/ethics, or historical culture can create the separation of nation or demanding of independence state (Juwono, 1985:16).

By re-establishing the Sultanate of Pattani Darussalam, the identity of Malay Muslim will come back as their original identity. PULO and Malay Muslim are realizing that identity is a heritage which must be protected and preserved. It can be done in order to respect as an ethnic identity that has existed for centuries. They can fight for their sovereignty as Malay Muslims who are able to stand up and up-grade their cultural roots as a national identity that should be respected by other countries.

\section{E. CONCLUDING REMARK}

Many countries have shown that the religion has a very close link with 
the politics and governmental system like with Buddha in the Kingdom of Thailand. Although beyond these facts, there are some people who are Muslims with Malay ethnicity who life in the southern part of Thailand, namely the provinces of Pattani, Yala and Narathiwat, coupled with Satun and Songkhla. The discrimination received by the Muslim Malay community in Southern Thailand coupled with development inequality, triggering the struggle against injustice and oppressive regimes which defined as jihad. Their movement manifested to various resistance organization. One of the biggest and most famous is the Pattani United Liberation Organization or PULO which established in 1968 by Kabir Abdul Rahman, a Malay Muslim scholar. From the perspective of Thai government, PULO is viewed as rebellion, separatist and terrorist. But on the contrary, from the perspective of Malay Muslim in the south, PULO is a real embodiment of jihad, struggle and heroism. In the beginning, PULO was established in order to fight toward Thai government discrimination toward Malay Muslim in Pattani. The PULO's jihad movements are basically motivated by various factors, among others: integration and assimilation policy factors, historical factors, economical factors, educational factors and cultural factors. Integration and assimilation policy factors highly discriminate the Malay Muslim community because the policy is based on "one religion, one empire, and bow to the power of the King" principle. It certainly hurt the Malay Muslim community, because historically the Islamic Sultanate of Pattani was sovereign and independent. Economically, almost the majority ethnic Malay Muslims live below the poverty line and living in a seedy neighborhood. In educational aspect, government policy is very difficult for the ethnic Malay Muslims to study the educational materials because it can only be presented in Thai language and writing. Overall things mentioned above led to a great culture shock to the Muslim Malay community. Later their jihad movement has been converted to local politics movement, where they want to have an authority to regulate the Pattani region by their self and even more extremely they want to secede from the Kingdom of Thailand to establish a state namely Pattani Darussalam. By re-establishing The Sultanate of Pattani Darussalam, the identity of Malay Muslim will come back as their original identity. PULO and Malay Muslim are realizing that identity is a heritage which must be protected and preserved.

\section{REFERENCES}

Abdillah, Ubed, (2002), Politik Identitas Etnis [Ethnicity Political of Identity], Magelang: Indonesia Tera.

Affandi, Hakimul Ikhwan, (2004), Akar Konflik Sepanjang Zaman: Elaborasi Pemikiran Ibn Khaldun [The Roots of Conflict in All Period: Elaboration of Ibn Khaldun's Thought], Yogyakarta: Pustaka Pelajar. 
Aphornsuvan, Thanet, (2003), History and Politics of the Muslim in Thailand, Bangkok: Thammasat University.

Biel, Eric et al. (ed.), (2005), "Losing Ground: Human Rights Defenders and Counterterrorism in Thailand", in Human Rights Defenders and Counterterrorism Series No. 4, New York and Washington: Human Right First.

Haboddin, Muhtar, (2012), "Menguatnya Politik Identitas di Ranah Lokal [Strengthened Political of Identity in the Local level]", in Jurnal Studi Pemerintahan Vol. 3, No. 1.

Jainuri, Achmad et al., (2003), Terorisme dan

Fundamentalisme Agama:

Sebuah Tafsir Sosial [Terrorism and the Religious

Fundamentalism: A Social Interpretation], Malang: Bayumedia.

Jory, Patrick, (2007), "Religious Labeling: From Patani Malayu to Thai Muslim", in Asia Research Institute Working Paper Vol. 18, No. 84.

Juwono (ed.), (1985), Ikatan-ikatan Primordial dan Politik Kebangsaan di Negara-Negara Baru dalam Pembangunan Politik dan Perubahan Politik [Primordial ties and National Politics in the New Countries in the Political Development and Political Change], Jakarta: Gramedia.

Kusuma, Bayu Mitra Adhyatma, (2015), Dialectic of Islam,
Politics and Government in Southeast Asian Countries: A Comparison of Indonesia and Thailand, presented at $6^{\text {th }}$ Joint International Conference and Graduate Workshop on Islamic Studies Revisited: New Trends in the Study of Islam and Muslim Societies, Yogyakarta, October 27-30.

Mahmud, Nik Anuar Nik, (2004), Sejarah Perjuangan Melayu Patani 1885-1954 [The Pattani Malay Struggling History 18851954], Negeri Sembilan: Saremban.

Miles, Matthew B. and Michael A. Huberman, (1998), Qualitative Data Analysis: A Source Book of New Methods, London: Sage Publication.

Punch, Keith F., (2004), Introduction to Social Research: Qualitative and Quantitative Approach, London: Sage Publication.

Sanak, Yohannes, (2014), Human Security dan Politik Perbatasan [Human Security and State Border Politics], ed. by Joash Tapiheru, Yogyakarta: PolGov.

Siddiqi, M. Yasin Mazhar, (2006), The Prophet Muhammad SAW: A Role Model for Muslim Minorities, Leicestershire: The Islamic Foundation.

Suaedy, Ahmad, (2010), "Islam and Minorities: Managing Identity in Malaysia", in Al-Jami'ah: Journal of Islamic Studies Vol. 48, No. 1.

Sunarto, Karmanto (ed.), (1985), Pengantar Sosiologi: Sebuah 
Bunga Rampai [Introduction to

Sociology: An Anthology],

Jakarta: Yayasan Obor

Indonesia. 